Western University

Scholarship@Western

Aboriginal Policy Research Consortium International (APRCi)

$3-2006$

\title{
Indigenous Research: Whose Priority? Journeys and Possibilities of Cross-Cultural Research in Geography
}

Paul Hodge

John Lester

Follow this and additional works at: https://ir.lib.uwo.ca/aprci

Part of the Other Geography Commons

Citation of this paper:

Hodge, Paul and Lester, John, "Indigenous Research: Whose Priority? Journeys and Possibilities of Cross-Cultural Research in Geography" (2006). Aboriginal Policy Research Consortium International (APRCi). 168.

https://ir.lib.uwo.ca/aprci/168 


\title{
Indigenous Research: Whose Priority? Journeys and Possibilities of Cross-Cultural Research in Geography
}

\author{
PAUL HODGE ${ }^{1 *}$ and JOHN LESTER ${ }^{2},{ }^{1 *}$ School of Environmental and Life Sciences, \\ University of Newcastle, Callaghan, NSW 2308, Australia. Corresponding author. Email: \\ pericles@ozemail.com.au; ${ }^{2}$ Umilliko Indigenous Higher Education Research Centre, \\ University of Newcastle, Callaghan, NSW 2308, Australia
}

Received 8 February 2005; Revised 28 June 2005; Accepted 17 November 2005

\begin{abstract}
Decolonising research in geography is part of a broader 'reflexive' process which continues to question the positivist status of 'researcher as observer'. This paper contributes to this reflexive turn, drawing on the particular experiences of a crosscultural Honours thesis. The paper is pursued through a parallel journey involving a non-Indigenous researcher (and author of the cross-cultural Honours thesis) engaging Indigenous research ${ }^{1}$ with interpretative insight from an Indigenous adviser or 'on-looker'. The methodological difficulties revealed by the parallel journey are emphasised to highlight both the complexities and reflexive possibilities of cross-cultural research but also to consider potential institutional and pedagogic implications that stem from the experience. One of the substantial findings of the paper is that, by linking Indigenous community priorities to research and coursework, conventional (and often unequal) research relations are minimised and colonising tendencies reduced. By challenging the conventional way that cross-cultural research is conceived, and the way that institutional practices and research frameworks are implemented, geographers can continue their prolonged and complex efforts at decolonisation of the field and their own practices.
\end{abstract}

KEY WORDS Reflexivity; human geography; Australia; decolonising research; ethics procedures; community-driven agendas; inter-subjectivities

\section{ACRONYM \\ HRAECG Hunter Region Aboriginal Education Consultative Group}

While at the philosophical level, geographers appear to be questioning belief in science as a completely rational, neutral and wholly objective activity, empirical research remains largely unaffected .... This continues to reinforce the positivist heritage of the discipline which, in the search for intellectual prestige, has attempted to emulate the methods of the natural sciences, thus imparting an objective aura to research (Harrison and Livingstone, 1980, 25).

\section{Introduction}

Over two decades ago Harrison and Livingstone (1980) observed that research methods within human geography were prefigured by the discipline's positivist legacy. They suggested that, unless the emerging voices of discontent within geography reformulated the discipline's foundational presuppositions, research methodologies could not be thrown open to revision. In the years following this call for action the notion of objectivity as underpinning intellectual prestige has been 
hotly contested. One set of challenges centres on the processes and procedures that constitute the act of research. This has been particularly evident in discussions within feminist geography on reflexivity and 'situated knowledges' (Haraway, 1988; McDowell, 1992; England, 1994; Nast, 1994; Kearns, 1997; Sutherland and Tandy, 1999; Twyman et al., 1999); in literature on the relationship between geography and ethics (Mitchell and Draper, 1982; Curry, 1991; Lake, 1993; Smith, 1997; Hay, 1998; Proctor, 1998); within quantitative/qualitative debates (Brannen, 1992; Hammersley, 1992; Winchester, 1996; 2000), and in cross-cultural or bi-cultural research contexts (Howitt et al., 1990; Teariki, 1992; McLean et al., 1997; Tuhiwai-Smith, 1999).

This paper develops the latter of these reformulations (of the discipline), placing it into a broader 'decolonising' framework with particular reference to geography in Australia and its relationship with Indigenous Australians (see Jacobs, 1996; Howitt and Jackson, 1998). It is suggested, in line with Howitt and Jackson's (1998) prognosis of the discipline, that significant contributions have been made in geography in terms of transcending colonial legacies, though remnants of the discipline's heritage continue to pervade the present. Geography's 'colonial baggage', suggest Howitt and Jackson (1998), is reflected in recent portrayals of Indigenous peoples that continue to render them invisible or irrelevant in Australia's landscapes. In this paper, the emphasis is on the contemporary research implications of geography's intellectual heritage which give primacy to the natural sciences and quantification as explanatory tools. The contention is that certain institutional settings and research practices constrain qualitative research undertaken by human geographers and that this limitation, in some University settings, impacts on the discipline's potential to embrace Indigenous research. A second position suggests that geographers have made intellectual, practical and political contributions to Indigenous Australians' opportunities to exercise their rights (Howitt and Jackson, 1998) and that this paper, aligned with these contributions, offers methodological possibilities centred around reciprocity and community agenda-setting. Part of the discipline's reformulation, then, involves breaking down the objective aura of research by nurturing a more interactive and collaborative view of research participants, particularly in cross-cultural contexts.

This paper has three aims. The first is to learn from and articulate the possibilities emerging from the particular experiences of a cross-cultural Honours thesis. Second, the paper argues that the institutional legitimation of qualitative methods in research is linked to (further) decolonising of the discipline; and third, that inter-subjectivities developed through community-driven agendas yield more responsible cross-cultural pedagogy. The paper is divided into two sections. Section One describes the processes of negotiation, realisation and transformation involved when the non-Indigenous author of the cross-cultural Honours thesis in question (Paul Hodge), aided by an Indigenous adviser and 'on-looker' (John Lester), detailed the background and context of the initial research project. Notably, Section One is developed through a parallel journey where the authors are distinguished by initials - John Lester (JL) and Paul Hodge (PH).

Section Two reflects on and develops several institutional and pedagogic implications that emerged from the cross-cultural Honours thesis. The first of these is the limiting aspects of the research ethics practices at the University of Newcastle, and here we consider the possibilities of more appropriate procedures and practices drawing on examples from other Australian universities. The second implication emerging from the cross-cultural Honours thesis involves linking community-driven agendas with Indigenous units (within Universities) to produce more responsible (and responsive) geography courses and research practice in cross-cultural settings. Here Spivak's (1996) notion of 'responsibility structure' is pertinent as an exemplar for this two-way flow of learning (see also McLean et al., 1997, 12, for an example in the Aotearoa/New Zealand context). A third implication developed from the cross-cultural Honours thesis, largely underpinning the latter, is the conceptual possibilities or methods of explanation that can emerge from 'collaborative negotiation' between academia and Indigenous communities in Australia.

'Negotiation' in the following parallel journey refers to the consultation process undertaken prior to and during the initial research project. 'Realisation' relates to concerns that emerged during the fieldwork, while 'Transformation' describes the subsequent re-focussing of the research due to fieldwork difficulties. The transition between the latter two stages, from realisation to transformation, consists of the critique of the 'initial research project' (the original aims and methods of the Honours thesis) contained in the 'cross-cultural Honours thesis' (eventual thesis submitted (Hodge, 1999)). 


\section{Section One: Negotiation, realisation, transformation}

\section{Negotiation}

$\mathrm{PH}$ The initial research project stemmed from a concern for the ongoing inequitable educational outcomes of Indigenous Australians ${ }^{2}$. Specifically, the aim was to reveal the attitudes of Indigenous students and parents (or relatives) on representations of Indigenous issues in the Geography syllabus at secondary schools using qualitative methods (focus groups).

Prior to undertaking the initial research project I approached John Lester, the Professor of the Umulliko Indigenous Higher Education Research Centre at the University of Newcastle to discuss ideas on a possible topic. At this meeting (where I was received cautiously) he suggested that I seek the guidance of a Koori co-researcher to act as a 'cultural facilitator' and potentially to assist my acceptance into local Indigenous communities. The guidance of a Koori co-researcher throughout the initial research project was aimed at ensuring adherence to cultural protocols ${ }^{3}$.

Assisted by a Koori co-researcher and Indigenous individuals within the Umulliko Indigenous Higher Education Research Centre and the Wollotuka Centre for Aboriginal Studies (also at the University of Newcastle), a draft of questions for the focus groups was developed. At the suggestion of JL the regional representative of the Hunter Region Aboriginal Education Consultative Group ${ }^{4}$ (HRAECG) was approached and requested to present the initial research project and focus questions to a regional meeting. Permission was granted and my session at the meeting confirmed. Following rigorous scrutiny and revision the initial research project and focus questions were received with broad approval.

$J L$ Confronted with the youthful enthusiasm and zest of a 'do-gooder' non-Indigenous commencing researcher, my task, as an Indigenous researcher and cultural mentor, was challenging from the start. As head of one of only six very recent innovative Indigenous Research Centres in Australia established by the then Department of Education, Training and Youth Affairs, my primary aim and mission was to empower Indigenous communities through Indigenous research (whatever this was to be defined as!). The focus of Umulliko is to support and develop Indigenous researchers and to explore with communities the advantages of sound, culturally-relevant research. The Centre's priority at this time was not to support even more colonising research by nonIndigenous researchers. Fitting the development of a young non-Indigenous researcher into a very competitive priority list of action for Umulliko appeared challenging, and this forced me as Chair of Aboriginal Studies to explore the role of non-Indigenous research in the context of the new, emerging, Indigenous research ownership field. This was a timely pursuit since an eminent Indigenous peer of Aotearoa/New Zealand, Linda Tuhawai Smith, had about this time released her major work on 'Decolonising Methodologies' (1999), which was extremely scathing of non-Indigenous research and its effects on Indigenous cultures.

The starting point was and always will be to seek Indigenous community support for the work and the best opportunity for this was to negotiate a time to meet with the HRAECG. At about this time I also suggested that an Indigenous co-researcher be brought on board to assist in the important community negotiations. The commencing researcher eagerly and, I believe, genuinely took on all advice rendered to him from Indigenous academics at the University. It was arranged that I be present at all Indigenous HRAECG meetings to assist at what can be a very challenging forum on most issues, and particularly challenging for a non-Indigenous researcher. Members of the group rigorously challenged the researcher's right to research this topic as a non-Indigenous person in the Indigenous domain. As mentor and keen observer of the Indigenous process, I stood back to see how the young researcher weathered the anticipated barrage of questions and testing of his bona fides. On several occasions after this initial testing period I provided advice and reassurance to the group about the nature and quality of the research and my confidence in the young researcher, which grew throughout the process and in some regard became a testing ground for the researcher to demonstrate his commitment and understanding of the Indigenous environment. Almost immediately after the researcher's mettle was tested by the HRAECG the mood swung to one of genuine support for the project and the researcher.

\section{Realisation}

PH Prior to undertaking the research I met with an Indigenous academic who had had extensive fieldwork experience with Indigenous communities throughout Australia. While she highlighted the importance of honesty and feedback when 
dealing with Indigenous communities, she identified a tendency for 'things that come up' to often disrupt the research process. For instance, she noted that I may go to the extent of ringing the participants weeks and days before the intended date of a meeting confirming times etc., to find that someone in the extended family may be sick or an event has been planned at the last minute.

During the intervals (of the HRAECG meeting) I was introduced to various people representing schools throughout the Hunter Region. While discussing the encouraging response to the research with several people, I was approached by a HRAECG committee member who told me quite candidly that, ' $[\mathrm{I}] \mathrm{f}$ there were more people in this room who were against you [as a nonKoori person] doing research on us [Koori people] then I would definitely be against it'.

One HRAECG representative expressed her interest in the project at the meeting and agreed to participate in the research. I sent the focus group material and cover letter for her perusal and to hand out to students and parents. I gave her several weeks to distribute the material and rang her after that time. She said that various family difficulties had cropped up and to give her a few weeks to sort things out. I rang her two weeks later and she simply said '[t]hings are going OK'. I left my contact number and address and suggested she ring me as soon as she was able to gather students together, but did not receive a reply.

$J L$ As is the case with many Indigenous students who are wrongly pronounced as 'failures' in the education system in Australia, this research was quickly drawing similar 'failed' status. However, it is not the student who is failing but the education system that is failing to meet the demands of the Indigenous students' and, in particular, the home communities' cultural demands. While the researcher in his reflections may initially have thought perhaps that the community had let him down, the reality was that the communities, in the most appropriate (and for them perhaps the most polite) manner, said 'no' to the research: not that the community did not wish to assist, but that the all-important completion of the research and the ultimate graduation of the researcher was, in reality, not a priority for the communities at this time.

The most fundamental consideration here is the question; whose research? The nature of the initial research project was designed to meet the perceived need of the researcher; it was researcher-centric in its conceptualisation, development, structure and boundaries, and was thus subsequently doomed to failure in its implementation in this form. Indigenous Australians are no longer interested in meeting research demands which are externally driven and have little ultimate benefit to meeting and improving their community demands. Regardless of the level of support from within Indigenous professional and community organisations for the research, his research topic had seemingly failed the most important test - local community acceptance.

\section{Transformation}

PH Following the standard academic procedures of collaboration and consent (with intended research participants), methodological difficulties emerged. Necessary communication for conducting the research became problematic, irregular, and finally absent. Significantly, the research participants involved had given consent to partake in the research. This contradictory juxtaposition, between consent and apparent indifference, was the impetus to consider the research context more closely. Following this disappointing response, and with a possibility that the entire thesis was at risk, particularly given the time constraints of an Honours program, I decided that an explanation of these fieldwork difficulties could constitute a legitimate (re)focus. Subsequently, an analysis of the methods and methodology of the initial research project became the focus for the cross-cultural research thesis. The (re)-focus involved two emphases.

First, The 'Application for Ethics Clearance' form for all university research involving human subjects at the University of Newcastle reflects a particular 'quantitative' focal point characteristic of its neo-positivist legacy and as such is limiting in its applicability for qualitative research ${ }^{5}$.

Second, the participants' experiences were invariably to be conceptualised within European theoretical constructs. The possibility of an Indigenous conceptual method of explanation an Indigenous 'way of seeing' - was completely excluded as a legitimate alternative. On this issue, Huggins (1998) questions the ways in which external (European) versions of 'us' pass for our (Indigenous) 'reality'. She argues that limits need to be placed on the ways in which our worlds are re-written or positioned within conceptual frameworks which are not our own. 
$J L$ The reflection of the researcher at this time is in reality the important research journey and poses the perplexing question of whose research and for whose ends? The young researcher's project underwent an amazing tranformation and, rather than contemplate its failure, he began to analyse the research system's failure to meet the needs of the community. The young non-Indigenous researcher in this instance actually gained most out of the exchange when the community forced him to pause and carefully take stock of his work. This period was particularly sobering for the researcher as such, and created a timeframe that did not fit within the academic constraints of completion of an Honours' program. Forced reflection provided the catalyst for the more important conceptual development of the researcher's understanding of cross-cultural research.

Sharing the journey with Indigenous peoples is the most important part of such a research or community development process. However, non-Indigenous researchers and, for that matter, emerging Indigenous researchers must be prepared to wait to be invited into the domain. No longer can researchers sit in ivory towers of supposed knowledge and dream up research topics, pedagogical and epistemological evolutions of Indigenous processes and outcomes. Local Indigenous communities have perhaps the most powerful of weapons to counter such attempts; the power to say 'no' to research. In this instance, the research did not proceed because the local community ultimately said no! not through such a statement, but through a polite process of seeing the research as unimportant to their daily lives, and hence according it a low priority. Institutional ethics committees and even community representative bodies like the HRAECG do not hold the ultimate sanction over appropriate research in Indigenous communities.

\section{Section 2: Research ethics procedures and cross-cultural pedagogy}

The spaces within the [dominant] research domain through which Indigenous research can operate are small spaces on a shifting ground. Negotiating and transforming institutional practices and research frameworks is as significant as the carrying out of actual research programmes (Tuhiwai Smith, 1999, 140, emphasis added).

This section reflects on and develops several institutional and pedagogic implications that emerge from the cross-cultural Honours thesis.
One of the critiques within the Honours thesis was of the 'quantitative' focal point of the research ethics application where it was suggested that this primacy indicated remnants of neopositivism. The contention was that this presented a limitation to the cross-cultural research context of the Honours thesis. The first part of this section develops this point where it is argued that research procedures should reflect acceptable and legitimate research practice in given institutional settings. In this case, some implications of the primacy of quantitative methods in ethics applications are considered insofar as they relate to the transformation described within the cross-cultural Honours thesis (Section 1). Examples from other Australian Universities' ethics procedures are used to highlight both the constraints on qualitative research undertaken in human geography at the University of Newcastle and the possibilities that can follow from more appropriate procedures and practices vis-à-vis cross-cultural research in geography.

The final part of Section 2 comprises two further implications stemming from the particular experience of the cross-cultural Honours thesis. The first of these is the idea of linking with community-driven agendas to produce more responsible (and responsive) Geography courses and research practice. Here, Indigenous Units or Departments at Universities could act as facilitators in an ongoing process whereby communities determine research priorities for undergraduate coursework or individual research projects. In this process, communities would be actively involved in the initial research agendas and outcomes, unlike the situation applying in more conventional research processes such as those which underpinned the initial research project (namely, identifying 'problems' to be 'solved' through investigation). The final implication emerging from the cross-cultural Honours thesis to be discussed in this paper involves concern over the inevitability that the participants' experiences were to be conceptualised within European theoretical constructs. At issue was the exclusion of an Indigenous conceptual method of explanation - an Indigenous 'way of seeing'. Guiding the approach to appropriate and inclusive research outcomes advocated in this paper is the position that bounded notions of self/ other, insider/outsider, are limiting in that these binaries represent 'others' as 'all-knowing subjects of otherness' (Katz, 1992). This position ultimately renders collaborative work incongruent 
(this joint paper is itself a response to such a position). Instead, the view is taken that none of us can be all-knowing subjectivities and that 'collaborative negotiation' indicative of an intersubjective approach provides the basis, in this case, for sustained decolonising of institutional practices and research frameworks in geography.

\section{Ethics procedures and Australian Geography programs: limitations and possibilities}

Geography in Australian Universities finds itself situated in a variety of institutional locations reflecting, among other things, its emerging crossdisciplinary links (Holmes, 2002). For those human geography groups located among the natural sciences this has led to a constraining research environment. This was certainly the case in respect to the ethics procedures preceding the 'acceptance' of the cross-cultural Honours thesis in question. Figure 1 shows the institutional setting of human geography at the University of Newcastle.

Significantly, human geography is one of the few subdisciplines in the Faculty where qualitative research methods are commonly used by researchers. Natural and behavioural sciences largely engender a particular positivist methodology in research procedures. For human geographers undertaking qualitative research, this has led to a necessary justification of these methods within positivist frameworks when obtaining ethics clearance ${ }^{6}$ (see also Winchester, 1996; Sutherland and Tandy, 1999). Thus, in answer to question 14 from the Ethics Application as part
Table 1 Selection of questions: The University of Newcastle, Faculty of Science and Mathematics, Application for Ethics Clearance for research with human subjects (Source: The University of Newcastle, 1998).

9. Explain (briefly and simply) the main scientific objectives or hypotheses of your study?

13. Are you taking any physical or physiological measurements of subjects?

14. Briefly describe the types of statistical analyses you intend to use? Why is your sample size appropriate, and how will these analyses meet your scientific objectives?

of the ethics procedure for the initial research project (Table 1), Hodge (1999) wrote:

[t]his project is very much of a qualitative nature. The methods chosen for obtaining data [focus groups] are extremely useful due to their interactive social context and have become increasingly recognised as potentially empowering for participants.

The epistemological base of these questions requires specific responses. Indeed, when responding to question 14 (Table 1) a position had to be argued in the above quotation as to why 'statistical analysis' was not ideal, and a proposition offered to state the potential benefits that openended dialogue can produce for participants against the detached and neutral position implied by the question.

There are several fundamental differences between quantitative and qualitative methods in

Faculty of Science \& IT

\section{Pro-Vice Chancellor's Office}

\begin{tabular}{|c|c|c|c|c|}
\hline \begin{tabular}{ll}
\multicolumn{2}{c}{ School of Applied } \\
- & Fcience \\
Food Science \\
Human \\
- & Nutrition \\
Herbal \\
Therapies \\
- Sustainable \\
$\quad$ Resource \\
Management
\end{tabular} & $\begin{array}{ll} & \frac{\text { School of }}{\text { Behavioural }} \\
- & \frac{\text { Science }}{\text { Aviation }} \\
- & \text { Psychology }\end{array}$ & 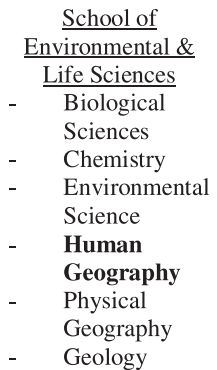 & $\begin{array}{ll}\frac{\text { School of }}{\text { Mathematical \& }} \\
\text { Physical Sciences } \\
- & \text { Mathematics } \\
- & \text { Physics } \\
- & \text { Statistics }\end{array}$ & $\begin{array}{l}\frac{\text { School of Design }}{\text { Comunication and }} \\
\underline{\text { Information }} \\
\text { Technology } \\
\text { Communication } \\
\text { \& Media Arts } \\
\text { - Visual Design \& } \\
\text { Natural } \\
\text { Illustrations } \\
\text { - Information } \\
\text { Systems } \\
\text { Information } \\
\text { Technology }\end{array}$ \\
\hline
\end{tabular}

Figure 1 Structure of Faculty: University of Newcastle, Faculty of Science and Information Technology. Source: Faculty of Science and Information Technology Postgraduate (Research) Information Booklet (2003). 
terms of their epistemological base. To state this, however, is not to favour the position of one set of methods over another or to diminish the potential of a mixed method approach. Qualitative methods provide unique knowledge about the complexities of the human condition and this uniqueness deserves a place of equal legitimacy in institutional settings. In terms of ethics applications, a more appropriate line of questioning is a necessary precursor to valuing this perspective. For instance, an application could involve a parallel stream or component of questions appropriate to qualitative aspects of the research with supporting details and evidence of academic rigour. Lincoln and Guba (1985) and Baxter and Eyles (1997) have detailed definitions, assumptions and strategies for evaluating qualitative research. Significantly, these forms of criteria acknowledge the multiple realities of research participants and the biases and motivations of the inquirer. They also require prolonged engagement with participants and peer examination of the inquirer's interpretations (Lincoln and Guba, 1985, see below).

Ethics procedures at La Trobe University (Victoria), Macquarie University (New South Wales) and Flinders University (South Australia) provide useful models for other universities in relation to the legitimation of qualitative methods. In the case of these universities, Ethics Applications (involving 'human subjects') give qualitative research methods equal status (with quantitative methods) in the application's content and design. This recognition evidently corresponds with the institutional location and context within which the research is positioned, in this case, such as the location of Geography within a Faculty of Social Sciences. In the case of Flinders University in South Australia, the 'Social' in the application title ('Application for Approval of Social or Behavioural Research Involving Human Subjects') has conceptual implications for the content (questions) in the application. Two examples are illustrated below (Table 2).

In question C3 (Table 2) neither quantitative nor qualitative methods are given priority, unlike the assumptions that underpin, for instance, question 14 of the University of Newcastle application (Table 1). The second question (D2, Table 2) reflects an understanding of group affinities and, in the case of research with Indigenous communities, establishes a link to further consultation with a mandatory submission to the Indigenous Unit. This requirement ensures
Table 2 Flinders University, Adelaide: Social and Behavioural Research Ethics Committee; Application for Approval of Social or Behavioural Research Involving Human Subjects (Source: Flinders University, no date indicated).

C3. Outline of research methodology. [Are] the data to be obtained primarily quantitative or qualitative? Is information to be sought by questionnaire, interview or a combination of both? Will participants be video- or tape-recorded?

D2. Indicate whether the participant group comprises a specific cultural/religious background, for example Aboriginal or Torres Strait Islander, Indonesian, Catholic, Muslim etc ..., or, if any such categories are likely to form a significant proportion of the population to be sampled. If the answer is yes and the group/sub-group is of Aboriginal or Torres Strait Islander background, a copy of this application must be submitted to the Director of Yunggorendi for advice and comment.

deliberations are made by an appropriate and representative body. A recent and timely development at the University of Newcastle vis-à-vis ethics procedures has been the establishment of the 'Peer Review of Methodology for Human Ethics Applications'. This new procedure is incorporated into the undergraduate, coursework and Honours application program within the Faculty of Science and Information Technology. Two promising developments identifiable in this submission process are, first, the attention to methodology and its justification; and second, the potential for feedback from outside the Faculty. In the case of cross-cultural research with Indigenous communities at the University of Newcastle this review process could be involved as a component within the submission process and involving the Umulliko Indigenous Higher Education Research Centre and the Wollotuka Centre for Aboriginal Studies (see below).

\section{Possibilities of cross-cultural pedagogy in geography}

Achieving spaces of dialogue between the identities of colonialism is a way of comprehending those other worlds so the boundary between the Other and the Self disappears in the research process (McLean et al., 1997, 12).

This concluding section comprises two further implications emerging from the particular experience of the cross-cultural Honours thesis: the 
potential for community-driven research agendas and the conceptual and explanatory possibilities that can develop from viewing knowledge construction as a two-way flow of learning (Spivak, 1996).

A key concern within the cross-cultural Honours thesis was the researcher-centred aims of the initial research project and the 'good intentions' that underpinned them. While a concern for the ongoing, inequitable educational outcomes of Indigenous Australians is merited, the externally-driven nature of the research aims was questionable and the possible gains for the Indigenous communities involved unclear. The suggestions outlined below form the basis for an approach that could inform the teaching of a cross-cultural methods course or core component of a qualitative methods course at undergraduate level. There may also be relevant implications for Honours or postgraduate research undertaken with Indigenous communities. Such an approach could help create, and learn from, '[a]chieving spaces of dialogue ...' (McLean et al., 1997, 12) and facilitate decolonising processes. Figure 2 outlines a flexible teaching and research guide where communities define research priorities.

The key aspect of the flexible guide is that the Indigenous community/ies define a particular set of research topics, ranging in focus and subject with a 'priority list' of issues or concerns. The role of the Indigenous Unit or Department would be to act as a 'facilitator' whereby a range of topics is further discussed with the community and appropriate topics 'attached' to particular research proposals or courses. The degree of appropriateness would depend on the relevant student level and associated timeframe open to the course or research undertaking.

The negotiated timeframe and activities would involve the total time given to students' immer-

Community: Collaborative Definition \& Power of Veto

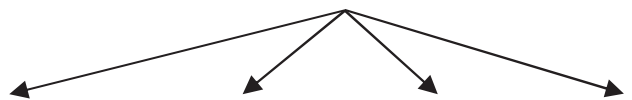

$\begin{array}{cccc}\begin{array}{c}\text { Research } \\ \text { Priorities/ } \\ \text { Course }\end{array} & \begin{array}{c}\text { Student } \\ \text { Level }\end{array} & \begin{array}{c}\text { Negotiation } \\ \text { Time frame } \\ \text { /Activities }\end{array} & \begin{array}{c}\text { Flexible } \\ \text { Format \& } \\ \text { Discussion }\end{array}\end{array}$

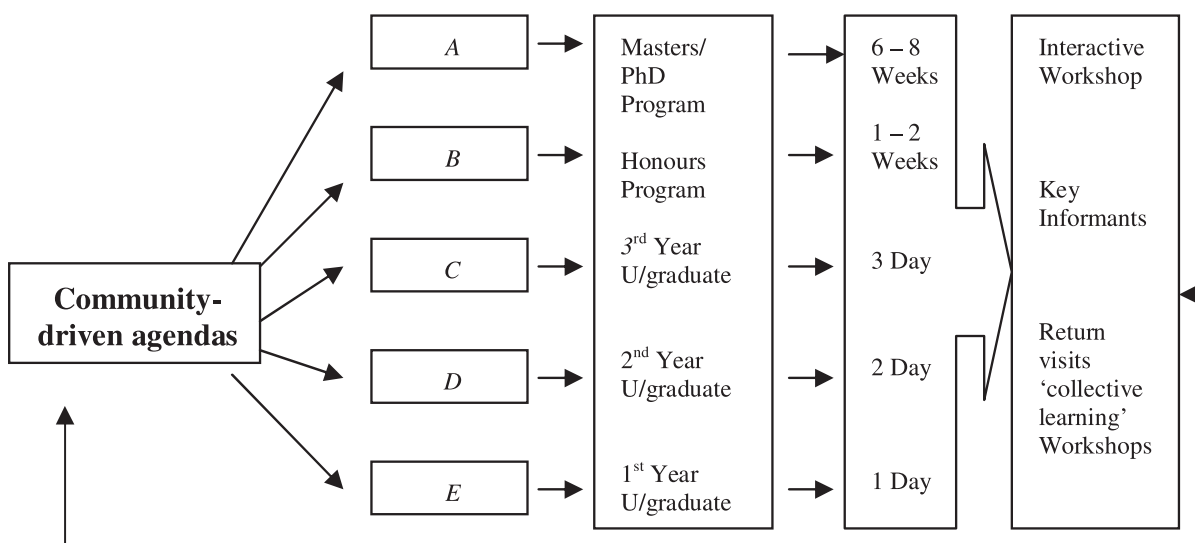

Research outcomes/ course findings: collective learning - 'Inter-subjectivity'

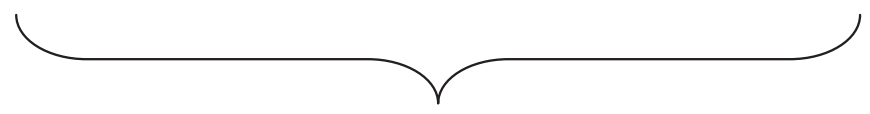

Indigenous Unit/ Department - 'Facilitator'

Figure 2 Flexible guide to teaching and research in cross-cultural contexts. Developed from Lester (1997). 
sion into the community/ies where interactive workshops, key informant presentations and return workshops are conducted. Negotiation over timeframes appropriate to a particular course or research undertaking could be one of the initial 'priority' issues discussed. An additional role for the Indigenous Unit or Department could be to coordinate continuity of research over time among multiple students as a way of addressing the limited time windows of student participation in programs and their possible lack of longer-term commitment to projects. A clear understanding of potential differences in concepts of time would also be an important consideration. This is particularly apparent because the time constraints of academia are limiting in that institutionalised education invariably requires time-bound 'outcomes', whereas issues or concerns pertinent to communities (Indigenous or non-Indigenous) rarely conform to such time specificities.

Several notable points can be made on the flexible teaching and research guide in relation to the research experience described in Section 1. First, the community-defined topic/s could ensure relevance of the research or course content. Within this Indigenous-led context the 'well-intentioned' are provided with a specific topic to undertake on the community's terms and subject to the community's current priorities. Second, workshops, particularly return workshops, provide opportunities to share research outcomes and course findings with the community/ ies. The workshops could also provide an opportunity to negotiate a conceptual framework Indigenous or non-Indigenous - which is conducive to the priorities sanctioned by the community and enables the potential for productive use of the ' $\ldots$ fruits of research' (Kearns, 1997, 6) ${ }^{7}$. The issue of researcher exploitation of participants or co-researchers is minimised in that communities are consistently kept up to date on 'their' research priority/ies and, ideally, community members participate in the analysis and formulation of findings, rather than merely commenting on them. The community-driven emphasis of the research proposal or course also lessens the chance of strong opposition to nonIndigenous involvement in Indigenous research processes. In the case of insurmountable differences of opinion, the communities involved will always hold the power to veto research proposals or course components. The "community ${ }^{8}$ referred to in the flexible guide could include a number of communities in various locations. Some communities may have issues or concerns which are appropriate to research only or conversely they could relate more to a community matter appropriate for inclusion in an undergraduate course.

Not surprisingly, given the complex nature of social research, there are potential problems facing a guide such as the one outlined here. For instance, there are no provisions for competing or conflicting community priorities. Second, who specifically is given the task of choosing research topics and then prioritising them? Here, the complex issue of 'gate keeping' becomes relevant. These kinds of research problems are not easily overcome. The challenge is to maintain dialogue and negotiated inter-subjectivities, both from within the academic institutions (between human geographers and academic staff of the Umulliko Indigenous Higher Education Research Centre, for instance) and among the communities involved.

\section{Conclusion}

This paper detailed the unpredictability of crosscultural research by describing some of the processes and procedures that constitute it. The methodological difficulties exposed by the parallel journey (Section 1) were emphasised to highlight the complexities and reflexive possibilities of cross-cultural research but also in order to consider the potential institutional and pedagogic implications that stem from the crosscultural Honours thesis (Section 2). The paper suggested, firstly, that geography has some way to go in 'breaking the shackles' of positivism, primarily in terms of institutional limitations, though there are precedents to be found in some Australian universities. Second, the paper linked the institutional legitimation of qualitative methods within geography to broader decolonising processes. Finally, the paper outlined a flexible guide for a cross-cultural pedagogy. Linking community-driven agendas to appropriate and responsive research and university courses can ensure more productive and less limiting relationships between researchers and those that make research possible. Ultimately, by challenging the conventional way that cross-cultural research is conceived, and the way that institutional practices and research frameworks are implemented, geographers can continue their prolonged and complex efforts at decolonisation of the field and their own practices.

\section{ACKNOWLEDGMENTS}

The authors would like to thank the research participants who took part in the early Honours program, including people within the Wollotuka Centre for Aboriginal Studies 
(Deirdre Heitmeyer and Joe Perry) and those holding various positions within the New South Wales Aboriginal Education Consultative Group (Nigel Parbury and Michael Donovan, in particular). The friendship and assistance of David Williams and Bruce Gorring are also warmly appreciated. For helpful comments on earlier versions of this paper we would like to thank Kate Hartig, Hilary Winchester, Steven Hodge and David 'Bruce' O'Brien.

\section{NOTES}

1. 'Indigenous research' is defined here in its broadest sense as research undertaken with communities (and prioritising their concerns) as opposed to conventional research practice on Indigenous peoples that often projects a 'detached' (and objective) researcher position.

2. In this paper descendants of the original inhabitants of Australia are referred to in accordance with their specific geographical location. 'Koori' is used to distinguish peoples from the south-eastern parts of Australia. Indigenous Australians, Indigenous peoples, Aboriginal peoples or Aboriginal and Torres Strait Islanders are also used in accordance with reference documents.

3. The Koori co-researcher and cultural facilitator was an undergraduate student undertaking a degree in secondary teaching at the time at the University of Newcastle.

4. The Hunter Region is located approximately 150 kilometres north of Sydney. The primary urban centre for the region is Newcastle.

5. Such positivist traditions (empirical observations) affront appropriate cross-cultural methodologies. Huggins (1998), for example, states that 'detached observer status is not advisable' (1998, 86-87) when nonAboriginal people write about Aboriginal people.

6. At the University of Newcastle, undergraduate coursework and Honours students are subject to Faculty Ethics procedures. For postgraduate student and staff research the University Ethics procedures are used. In this case, the Honours thesis was subject to the Faculty Ethics procedures and, when referring to 'human geography research', we refer specifically to this particular ethics process.

7. Workshops do not always flow unproblematically in the way described here (as the experience of trying to organise the focus groups in the initial research project illustrates). Individual, group and/or household dynamics can affect attendance, participation and openness of communication.

8. 'Community' is a complex and often contested term which tends to mask the differences that can exist within it (see Ruming et al., 2004 on various notions of community).

\section{REFERENCES}

Baxter, J. and Eyles, J., 1997: Evaluating qualitative research in social geography: establishing rigour in interview analysis. Transactions, Institute of British Geographers 22, 505-525.

Brannen, J., 1992: Combining qualitative and quantitative approaches: an overview. In Brannen, J. (ed.) Mixed Methods: Qualitative and Quantitative Research. Ashgate Publishing, Avebury, UK, 4-37.

Curry, M.R., 1991: On the possibility of ethics in geography: writing, citing and the construction of intellectual property. Progress in Human Geography 15, 125-147.

England, K.V.L., 1994: Getting personal: reflexivity, positionality, and feminist research. Professional Geographer $46,80-89$.
Flinders University, no date: Social and Behavioural Ethics Committee: Application for Approval of Social or Behavioural Research Involving Human Subjects. Flinders University, Adelaide.

Hammersley, M., 1992: Deconstructing the qualitativequantitative divide: an overview. In Brannen, J. (ed.) Mixed Methods: Qualitative and Quantitative Research. Ashgate Publishing, Avebury, UK, 39-56.

Haraway, D.J., 1988: Situated knowledges: the science question in feminism and the privileges of partial perspective. Feminist Studies 14, 575-599.

Harrison, R.T. and Livingstone, D.N., 1980: Philosophy and problems in human geography: a presuppositional approach. Area 12, 25-31.

Hay, I., 1998: Making moral imaginations: research ethics, pedagogy and professional human geography. Ethics, Place and Environment 1, 55-76.

Hodge, P., 1999: Silences in the Social Sciences - A Critique of Cross-cultural Methodologies. Unpublished B.A. (Honours) thesis, School of Geosciences, The University of Newcastle, Newcastle, Australia.

Holmes, J.H., 2002: Geography's emerging cross-disciplinary links: process, causes, outcomes and challenges. Australian Geographical Studies 40, 2-20.

Howitt, R. and Jackson, S., 1998: Some things do change: indigenous rights, geographers and geography in Australia. Australian Geographer 29, 155-173.

Howitt, R., Crough, G. and Pritchard, B., 1990: Participation, power and social research in Central Australia. Australian Aboriginal Studies 1, 2-10.

Huggins, J., 1998: Sister Girl. University of Queensland Press, St Lucia, Australia.

Jacobs, J.M., 1996: Edge of Empire: Postcolonialism and the City. Routledge, London.

Katz, C., 1992: All the world is staged: intellectuals and projects of ethnography. Environment and Planning D: Society and Space 10, 495-510.

Kearns, R.A., 1997: Constructing (bi)cultural geographies: research on and with people of the Hokianga District. New Zealand Geographer 53, 3-8.

Lake, R.W., 1993: Planning and applied geography: positivism, ethics and geographical information systems. Progress in Human Geography 17, 404-413.

Lester, J., 1997: Researching With Respect: Narratives of Experience When Researching Within Indigenous Contexts. Researcher Experiences of John Lester. Unpublished Paper, University of New England, Armidale.

Lincoln, Y. and Guba, E., 1985: Naturalistic Inquiry. Sage, Beverly Hills, United States of America.

McLean, R., Berg, L.D. and Roche, M.M., 1997: Responsible geographies: co-creating knowledge in Aotearoa/New Zealand. New Zealand Geographer 53, 9-15.

McDowell, L., 1992: Doing gender: feminism, feminists and research methods in human geography. Transactions, Institute of British Geographers 17, 399-416.

Mitchell, B. and Draper, D., 1982: Relevance and Ethics in Geography. Longman, London.

Nast, H.J., 1994: Opening remarks on 'Women in the Field'. Professional Geographer 46, 54-66.

Procter, J.D., 1998: Ethics in geography: giving moral form to the geographical imagination. Area 30, 8-18.

Ruming, K.J., Mee, K.J. and McGuirk, P.M., 2004: Questing the rhetoric of social mix: courteous community or hidden hostility? Australian Geographical Studies 42, 234-248.

Smith, D.M., 1997: Geography and ethics: a moral turn? Progress in Human Geography 21, 583-590. 
Spivak, G.C., 1996: Subaltern talk. In Landry, D. and MacLean, G. (eds) The Spivak Reader. Routledge, London, 287-308.

Sutherland, E.A. and Tandy, C.A., 1999: Challenges of Cross-Cultural Research: Methods and Processes. Paper presented to the Inter-cultural Studies Conference, Newcastle, Australia.

Teariki, C., 1992: Ethical issues in research from a Maori perspective. New Zealand Geographer 48, 84-86.

Tuhiwai-Smith, L., 1999: Decolonising Methodologies Research and Indigenous Peoples. University of Otago Press, Dunedin, New Zealand.

Twyman, C., Morrison, J. and Sporton, D., 1999: The final fifth: autobiography, reflexivity and interpretation in cross-cultural research. Area 31, 313-325.
University of Newcastle, 1998: Faculty of Science and Mathematics: Application for Ethics Clearance for Research with Human Subjects. University of Newcastle, Newcastle, Australia.

University of Newcastle, 2003: Faculty of Science and Information Technology: Postgraduate (Research) Information Booklet. University of Newcastle, Newcastle, Australia.

Winchester, H.P.M., 1996: Ethical issues in interviewing as a research method in human geography. Australian Geographer 26, 117-131.

Winchester, H.P.M., 2000: Qualitative research and its place in human geography. In Hay, I. (ed.) Qualitative Research Methods in Human Geography. Oxford University Press, Melbourne, 1-22. 